\title{
The Implementation of 2013 Curriculum in Elementary Schools
}

\author{
Ahmad Syarif \\ Faculty of Sport Sciences \\ Yogyakarta State University \\ Yogyakarta, Indonesia \\ ahmadsyarif.2017@ student.uny.ac.id
}

\author{
Tomoliyus \\ Faculty of Sport Sciences \\ Yogyakarta State University \\ Yogyakarta, Indonesia \\ tomoliyus@uny.ac.id
}

\author{
B. M. Wara Kushartanti \\ Faculty of Sport Sciences \\ Yogyakarta State University \\ Yogyakarta, Indonesia \\ wara@uny.ac.id
}

\begin{abstract}
-this study is aimed at describing the implementation of the 2013 curriculum in elementary schools in Sleman district of Yogyakarta. The research type is field research with qualitative approach. With a research subject on physical education teacher, sport, and health the research objects are the first and fourth grade thematic learning, conducted in academic year 2017/2018. Data collection is carried out by a method of observation, interview, and documentation, data analysis by Matthew B. Milles and A. Michael Huberman with flow models. The result of interdisciplinary integrative thematic learning is gotten from the physics, sports, and health teachers of first and fourth grade by integrating the dimension of attitude, knowledge, and skills into a unified whole. This integrative thematic learning provides an opportunity for students to develop three main domains of educational goals simultaneously from attitudes, knowledge and skills, enabling students to integrate information and topics in a variety of learning experiences. Implementing a new curriculum in the world of education began from the implementation of the 2013 curriculum in elementary schools. Implementation of the 2013 curriculum is expected to provide impetus for improvement in the quality of management and processing as an effort to improve education in every dispensation. Outcomes of students' learning with the curriculum in Indonesia have internal challenges related to the eight national education standards.
\end{abstract}

Keywords-Implementation, Curriculum 2013, Integrative Learning in Primary School.

\section{INTRODUCTION}

Implementation of the new curriculum in 2013 is aimed at improving the quality of education[4]. The result of observing 26 elementary schools in Bandung shows that the lecture method is still used in learning process in the first grade to the sixth grade [7]. There are different causes of success factors in applying the curriculum. The process dimension is the implementation of what is planned in the document dimension [14]. As a result of the changes in the demands of the global world, there should be a conduction of SWOT analysis and labor market signals for an internationally accepted curriculum in accelerating changes in the science, technology and curriculum paradigm shift [16]. Government policies are continually being made and there are many individuals involved in formulating educational policies in practice even without being in power [5]. The 2013 curriculum is conducted to educate students on learning and preparation of skills in the 21 st century by providing an understanding of the skills needed through innovative learning [3].
Learning expenses are spent in hours of study each week for one semester. The burden of learning in elementary schools of Tahin I, II, and III is 30, 32, 34 respectively, while for classes IV, V, and VI is 36 hours per week for each, with a one-hour time allocation in elementary school [8]. Integrated thematic themes in elementary schools cannot be separated from the development of an integrated approach to the concept of learning. The integrated approach starts from the concept of an integrated interdisciplinary curriculum. A fully integrated curriculum can be achieved through the convergence of lessons on specific issues and alternative solutions, using various disciplines [8].

The 2013 curriculum is actively part of the improvement in the quality of education in Indonesia through the three levels: knowledge, attitude, and skills [13]. The integrated approach starts from the concept of integrated interdisciplinary curriculum. The integrated curriculum tends to be of the view that the subject must be fully integrated. Integration can be achieved through convergence of lessons on a specific problem with alternative solutions from the various disciplines required so as to eliminate boundaries between subjects.

The integrated curriculum provides an opportunity for students to study in groups or individually by empowering communities as sources of learning which in turn aids fulfillment of individual learning. Integrative thematic learning in Elementary Schools should be added the same manner by strengthening character education on national educational goals: religion, honesty, tolerance, discipline, hard work, creative, independent, democratic, curiosity, nationalism, patriotism, , friends, love peace, love, reading, caring environment, social care, responsibility [6].

Elementary School Teachers in Indonesia are propelled to implement the required academic qualifications, competencies and certificates of educators, being physically and mentally healthy and have the ability to achieve the goals of national education [16]. The curriculum of 2013 should also focus on Bloom's taxonomy in the development of cognitive, affective and psychomotor potentials, also taking into account the view of multiple intelligences. Nine types of multiple intelligences are linguistic, logical-mathematical, visual, kinesthetic, musical, interpersonal, intrapersonal, naturalist and existential [9]. In the implementation of the 2013 curriculum, the central government established some national standards: outcome standards, process standards, assessment standards, basic frameworks and curricula, syllabus and textbooks for teachers and students, conduction of training on both principals, supervisors, core teachers, 
teacher trainers and mass-teacher, eventually returning to teachers in elementary school for any desire to change learning [16].

\section{CURRICUlum IMPLEMENTATION}

\section{A. Curriculum Implementation}

Understanding implementation as a language in the Oxford Advance Learner dictionary cited [12] it as "putting something info effect" (Application of something that gives effect or impact) [2]. Implementation is the extension of activities to adapt to the others and implementation is defined as the process of implementing ideas, concepts. The curriculum is a document that is clearly defined (curriculum potential) Application of the curriculum is the application of ideas, potential curriculum concepts (in the form of curriculum documents) into the actual form of the learning curriculum.

Teachers become central figures in the implementation of the curriculum. Primary school teachers in Indonesia must have academic qualifications, competence, teaching certificate, physical health, spiritual health and also have the ability to achieve the goals of national education. Competency authority is authority to determine or decide a case. Understanding the basic competence (competence) is the ability and greatness [11]. Competence in this context is a set of knowledge, skills, necessary behaviors which the teacher must live and be governed by, in order to carry out the task of professionalism. Competent teachers can perform their duties professionally.

\section{B. Curriculum Structure In Basic School}

The curriculum structure consists of subjects, study load, and educational calendar [8]. Subjects are composed of compulsory subjects and elective subjects. Compulsory subjects must be learnt by all students in educational units at every level of education. Elective subjects are learnt by students according to the student's choice. Both subject groups are developed in the structure of the secondary education curriculum. In consideration of the age and psychological development of students aged 7 - 15 years, elective lessons have not been provided for elementary and junior high school students.

TABLE I. STRUCTURE OF THE CURRICULUM IN ELEMENTARY SCHOOL

\begin{tabular}{|c|c|c|c|c|c|c|c|}
\hline \multirow{2}{*}{\multicolumn{2}{|c|}{ MATA PELAJARAN }} & \multicolumn{6}{|c|}{ alokasi waktu belajar per minggu } \\
\hline & & I & II & III & IV & $\mathrm{V}$ & VI \\
\hline \multicolumn{2}{|c|}{ Kelompok A } & & & & & & \\
\hline 1 & Pendidikan Agama & 4 & 4 & 4 & 4 & 4 & 4 \\
\hline 2 & Pendidikan Pancasila dan Kewarganegaraan & 5 & 6 & 6 & 6 & 6 & 6 \\
\hline 3 & Bahasa Indonesia & 8 & 8 & 10 & 10 & 10 & 10 \\
\hline 4 & Matematika & 5 & 6 & 6 & 6 & 6 & 6 \\
\hline \multicolumn{2}{|c|}{ Kelompok B } & & & & & & \\
\hline 1 & $\begin{array}{l}\text { Seni Budaya dan Keterampilan (termasuk muatan } \\
\text { lokal) }\end{array}$ & 4 & 4 & 4 & 6 & 6 & 6 \\
\hline 2 & $\begin{array}{l}\text { Pendidikan Jasmani, Olahraga dan Kesehatan } \\
\text { (termasuk muatan lokal) }\end{array}$ & 4 & 4 & 4 & 4 & 4 & 4 \\
\hline \multicolumn{2}{|r|}{ Jumlah Alokasi Waktu Per Minggu } & 30 & 32 & 34 & 36 & 36 & 36 \\
\hline
\end{tabular}

Integrative thematic themes are not integrated from development, the integrated approach begins from the concept of integrated interdisciplinary curriculum. A freely integrating curriculum can lead to convergence on specific issues with alternative solutions from various disciplines [8]. Every student also has their own belief in solution [1].

\section{RESEARCH METHODS}

Te research method used is that of qualitative research. The subjects of this study were teachers at elementary schools in Sleman regency, Yogyakarta. To be specific, they are; Mancasan Elementary School, Muhammadiyah Balecatur Elementary School, and Elementary School of IT Jabal Nur Gamping. This was where integrative thematic research was conducted by physical, sports and health education teachers in grade 1 and grade 4. Data was collected in the form of words through teacher and student interaction activities. Integrative thematic focus of research was done with observation, interview and documentation [10]. Observation method was simply to observe the integrative teacher thematic learning done in class 1 and 4 , because it is the class which makes use of the 2013 curriculum with integrative thematic in the academic year 2017-2018. Observation instruments are in the form of observation sheets and interview method is in the form of questions and answers from principals and teachers. Documentation method is in the form of a copy of education service documents related to the 2013 curriculum, essence of competence, basic competence, syllabus, lesson plan, teacher and student handbook.

Analysis of qualitative data with flow model, includes three components; collection of data along with data reduction which is done by electoral process, focus and simplification of abstraction and transformation of raw data, data analysis in the form of data presentation consisting of a set of information prepared and conclusion applied in analysis with integrative thematic learning theory.

\section{RESUlTS AND DISCUSSION}

The thematic integrative learning is carried out by first and fourth grade primary teachers, which includes preparation of lesson plans, developed by a group of teachers in teacher group activities with reference to the syllabus. The learning process is a learning activity that comprises of: Introduction, core and cover. The core activities are details of exploration, elaboration, and confirmation activities, consisting of five learning experiences: observing, asking, gathering information, associating, communicating [15] and assessment of learning. Assessment of integrated thematic learning refers to the basic competency indicators of each subject which are integrated into it and can be explained as follows.

\section{A. Preparatory Learning Plan for Integrative Thematic Curriculum 2013}

The first stage in integrative thematic learning for teachers is the implementation of RPP. One of them is the theme of the family of the LP class and the sub-themes in my family for the four classes which includes the LP theme, the energy saving sub theme of power and movement. Lesson plans developed by teachers include: school data, lessons, and classes, sub theme, Time Allocation, Essential Competence (EC), learning objectives, basic competencies and indicators of achievement of competencies, learning materials. learning methods, media, tools and learning resources, steps of learning activities and assessment. 
In the family theme of the LP class and the sub theme of family members, the friend is the integration of basic competencies and Indicators of Indonesian subjects; civic and cultural education. For the fourth-grade learning plans on themes, always save energy sub themes of strength and motion. They are integrations of Basic Competencies and Indicators which are used to teach science, Indonesian culture and civic education. Also integrated core competencies are First core competencies in terms of spiritual attitudes, second core competencies in social attitudes, third core competencies with respect to knowledge, and fourth core competencies related to skills (Minister of Education Regulation No. 69: 2013). The development of integrative thematic learning in teachers' lesson plans is conducted in groups so that LP can be given at the beginning of each school year.

\section{B. Learning Process Thematic Integrative Curriculum 2013}

The second stage of learning is a thematic integrative curriculum learning process of 2013 in first and fourth grade, explaining that learning activities refer to LP that have been developed by teachers. Learning activities consist of; Introduction, core, and Closure. The core activities detailed in exploration, elaboration, and confirmation activities are: observing, asking, gathering information, linking and communicating.

On the theme of family, with the sub-theme of their family members, the integration of Basic Competence (SM) and Indicators of Indonesian subjects, PPKn and SBdp. Students' learning process is required to collect family photos, then students are asked to observe each family photo, to be matched on the pictures are incomplete cards written 'my father', 'mother', 'brother' and 'daughter' by a teacher. Students apply straight and curved lines to complete picture cards and then associates or analyze the meaning of the word "brother". The students are asked to make a question about who the brother is? Then the students collect information from the student handbook, and communicate the results. "Sisters" are older family members. The teacher asks the students to discuss the group with the teacher directed to the student. It can be summed up by associating, analyzing and communicating what has been discovered in "sister" group activities.

From the direct learning process, knowledge is generated on the concept of family and family members. In questioning skills, students are trained to use questions, some learners still need to ask the teacher for help in asking questions while there is a level of students who can ask questions independently. Through asking, curiosity is being grown, the more trained in asking, the higher the growth of curiosity. Information delivery as a form of oral transmission is also in the form of writing. The competence of Indonesian language i.e cultural competence has an effect on the ability of learners to create curved lines and color drawing family card.

While studying indirectly, the form of developing the core competence of spiritual attitudes "Living and practicing the teachings of religion" is delivered at the beginning of the teaching activity. The teacher asks the students to pray according to their respective religions and beliefs and also greetings. The current core activity which is "to create a straight line and curved" through the family graphics card, the teacher instructs the students to color the picture by saying that God (Allah) is the Most Beautiful who creates various colors, as well as the teacher explaining to them that" Having a family is a gift to be cherished, as a form of our gratitude to God who has created a family for us ". EC-2, is the core competence of social attitudes. Living and practicing discipline, accountability and responsiveness in accomplishing tasks conveyed by the teacher. In integrated thematic learning, it can take the form of Intra-discipline, done by integrating the dimensions of attitude, knowledge, and skills to be in coherent unity during each lesson. Interdisciplinary integration is done by combining the competencies of some basic lessons and linking them up with each other, so as to reinforce each other, avoid overlap, and maintain learning alignment.

For the fourth-grade lesson plans on themes, always save energy sub themes of strength and motion. The integration of Basic Competencies and Indicators is used to teach science, Indonesian culture and civic education, employing construction materials with the power of friction cargo science. Indonesian students are required to write observation activities, creative culture made of natural materials and civic education that gotten from a uniform attitude.

In sub-themes of strength and movement in learning activities, students learn individually by utilizing playing marbles, playing dice. Teachers should also take turns playing marbles and dice. running shoes rough and plain, and learning groups which are used to make creative works such as carfrom the skin of a watermelon fruit. In an individual lesson, students are asked to observe and experience how strength and movement changed when marbles and dice have been played, as well as to distinguish coarse and fine footwear, then this is written in observational reports. In this learning process, learners build knowledge, thinking skills and psychomotor skills. By being in a working group and taking active part in creative works in the form of toy cars from watermelon, learners build knowledge, thinking skills and psychomotor skills in training and unite in realizing the car works. Direct instruction for students with creativity formation, with the provision of a number of activities, the natural atmosphere takes into account the students' experience in an integrated and non-partial way, their integration and Basic Competency Indicators of the subjects of science, Indonesian language, culture and civic education.

\section{Assessment of Integrated Thematic Learning}

Third stage of integrated Thematic Assessment is to know the achievement of SM based on teacher indicator developed, referring to basic competence indicator of family theme and sub-theme of family member. Theme is an integration of basic competence and indicator of Indonesian subject; Civic and Cultural Education. For fourth-grade, lesson plans on themes are always saving energy sub themes of power and motion, their integration of Basic Competencies and Indicators to teach science, Indonesian culture and civic education. Each subject is integrated into the theme of the composed material when using test in written or oral form, performance observation, attitude measurement and job assessment in product form.

In carrying out the evaluation of teachers' learning and assessment process, there are outcomes on aspects of attitude, knowledge and skills. Assessment is directed to measure the achievement of competence i.e CD on EC-3 and 
EC-4. Assessment using reference criteria is based on what the learner can do after the learning process and not determining one's position to the group. The planned system is a continuous assessment system, continuous in the sense that all indicators are imposed and the results are analyzed to determine which $\mathrm{BC}$ has been owned and who has not, and also to be certain of learners' difficulties. Assessment results are analyzed to determine improvement programs for students who achieved competence under a program of thoroughness and also to enrich students who have fulfilled the completeness.

\section{CONCLUSION}

Implementation of integrative thematic curriculum in 2013 is done by integrating the three learning domains of attitude, knowledge, and skills into student learning outcomes. The learning competencies of the three basic subjects and the four subjects become interrelated subjects, giving each other strength while aligning each subject. Integrated thematic learning emphasizes opportunities for students to develop learning outcomes through those three domains in order to integrate information obtained by students in each learning topic through learning experience. Indonesia always makes dynamic curriculum changes as education is always modified as a result of new developments in the field of science, technology and art, including changes in the mindset of the community towards education improvement.

\section{REFERENCES}

[1] A. Shaibu, A. Mat, and A. Rahim, "Predictor of career adabtability skill among higher education students in Nigeria", IJRVET, Vol 3, pp 212-229, Desembar 2016.

[2] Binti Maunah, 2009, pengembangan kurikulum berbasis kompetensi implementasi pada tingkat pendidikan dasar (SD/MI), Yogyakarta: Teras.
[3] C. Kivunja, "Teaching students to learn and to work well with 21 ST century skills: unpacking the career and life skills domain of the new learning paradigm", International Journal of Higher Education, Vol 4, Oktober 2014

[4] H. Retnawati, S. Hadi, and A. C. Nugraha, "Vocational high school teacher's in implementing the assessment in curriculum 2013 in Yogyakarta Province of Indonesia", International Journal of Instruction, Vol 9, pp 33-48, Januari 2016.

[5] J. Jimerson and J. Child, "Signal and Symbol: How state and local policies address data-informed practice", Education Policy, Vol 31, pp 584-614, 2017.

[6] Kemendiknas, 2010, pengembangan pendidikan budaya dan karakter bangsa pedoman sekolah, Jakarta: Kemendiknas Balitbang Puskur.

[7] K. Hilda, "Perbedaan kurikulum KTSP 2006 dan kurikulum 2013 untuk jenjang sekolah dasar", Jurnal Pendidikan Penabur, Vol 13, pp 84-96, Juni 2014.

[8] K. P. Kebudayaan, "Dokemntasi kurikulum 2013", Kementerian Pendidikan dan Kebudayaan, 2013.

[9] L. Alviares, L. Romero, and K. Garcia, "Implications and applications of multiple intelligences theory in scond language education: A Review”, SJER. Venezuela, Vol 3, pp 016-023, Februari 2015.

[10] Matthew B. Miles dan A. Maichael Huberman, Analisis data kualitatif buku sumber tentang metode-metode baru, Terj. Jakarta: Universitas Indonesia (UI Press). 1992.

[11] Moh. Uzer Usman, menjadi guru professional, Bandung: Remaja Rosda Karya. 2006.

[12] Mulyasa, Implementasi kurikulum tingkat satuan pendidikan: Kemandirian guru dan kepala sekolah, Jakarta: PT. Bumi Aksara. 2008.

[13] Rosmani, A. Halim, "Analisis perbandingan hasil belajar kimia siswa terhadap penerapan KTSP dan kurikulum 2013 di beberapa sekolah favorit Banda Aceh", Jurnal Pendidikan Sains Indonesia, Vol 5, pp 94101, 2017.

[14] Rusman, "Curriculum implementation at elementary schools a study on "Best Practices" done by elementary school teachers in planning, implementing, and evaluating the curriculum", Journal of education and practice, Vol 6, pp 106-113, 2015.

[15] Salinan lampiran Peraturan Menteri pendidikan dan kebudayaan RI nomor 65 tahun 2013 tentang standar proses pendidikan dasar dan menengah.

[16] W. Hidayati, "Impelemtation of curriculum 2013 in Primary school Sleman Yogyakarta", IOSR-JRME, Vol 6, pp 06-12, April 2016. 